\title{
ON REFINEMENTS OF HERMITE-HADAMARD TYPE INEQUALITIES WITH GENERALIZED FRACTIONAL INTEGRAL OPERATORS
}

\author{
HÜSEYIN BUdAK* AND MEHMET ZEKI SARIKAYA
}

\begin{abstract}
In this paper we establish the refinements of Hermite-Hadamard type inequalities for
\end{abstract} generalized fractional integral operator through the instrument of convex functions.

Mathematics subject classification (2020): 26D15, 26B25, 26D10.

Keywords and phrases: Hermite-Hadamard inequality, fractional integral operators, convex function.

\section{REFERENCES}

[1] R. P. Agarwal, M.-J. Luo And R. K. Raina, On Ostrowski type inequalities, Fasciculi Mathematici, 204, De Gruyter, doi:10.1515/fascmath-2016-0001, 2016.

[2] G. A. Anastassiou, General Fractional Hermite-Hadamard Inequalities Using m-Convexity and $(s, m)$-Convexity, Frontiers in Time Scales and Inequalities, 2016, 237-255.

[3] A. G. AzPeitia, Convex functions and the Hadamard inequality, Rev. Colombiana Math., 28 (1994), $7-12$.

[4] H. Budak, F. Usta, M. Z. Sarikaya And M. E. Özdemir, On generalization of midpoint type inequalities with generalized fractional integral operators, Revista de la Real Academia de Ciencias Exactas, Físicas y Naturales, Serie A. Matemáticas 113.2 (2019): 769-790.

[5] H. Chen and U. N. Katugampola, Hermite-Hadamard and Hermite-Hadamard-Fejér type inequalities for generalized fractional integrals, J. Math. Anal. Appl. 446 (2017) 1274-1291.

[6] S. S. Dragomir And C. E. M. Pearce, Selected Topics on Hermite-Hadamard Inequalities and Applications, RGMIA Monographs, Victoria University, 2000.

[7] S. S. DRAGOMiR, Two mappings in connection to Hadamard's inequalities, J. Math. Anal. Appl., 167 (1992), 49-56.

[8] A. E. FARISSI, Simple proof and re nement of Hermite-Hadamard inequality, J. Math. Inequal., 4 (2010), 365-369.

[9] R. Gorenflo, F. MAInARd, Fractional calculus: integral and differential equations of fractional order, Springer Verlag, Wien (1997), 223-276.

[10] M. IQbal, S. QAisar And M. Muddassar, A short note on integral inequality of type HermiteHadamard through convexity, J. Computational analaysis and applications, 21 (5), 2016, pp. 946-953.

[11] A. A. Kilbas, H. M. Srivastava and J. J. Trujillo, Theory and Applications of Fractional Differential Equations, North-Holland Mathematics Studies, 204, Elsevier Sci. B. V., Amsterdam, 2006.

[12] M. A. Noor AND M. U. AwAN, Some integral inequalities for two kinds of convexities via fractional integrals, TJMM, 5 (2), 2013, pp. 129-136.

[13] M. A. Noor, K. I. Noor AND M. U. Awan, New fractional estimates of Hermite-Hadamard inequalities and applications to means, Stud. Univ. Babess-Bolyai Math. 61 (2016), No. 1, 3-15

[14] M. A. Noor, G. Cristescu And M. U. Awan, Generalized fractional Hermite-Hadamard inequalities for twice differentiable s-convex functions, Filomat 29:4 (2015), 807-815

[15] J. E. PeČarić, F. Proschan and Y. L. Tong, Convex Functions, Partial Orderings and Statistical Applications, Academic Press, Boston, 1992.

[16] R. K. RAINA, On generalized Wright's hypergeometric functions and fractional calculus operators, East Asian Math. J., 21 (2) (2005), 191-203. 
[17] M. Z. SARIKAYA AND H. YILDIRIM, On Hermite-Hadamard type inequalities for Riemann-Liouville fractional integrals, Miskolc Mathematical Notes, Vol. 17 (2016), No. 2, pp. 1049-1059.

[18] M. Z. SARIKAYA AND H. OgunMeZ, On new inequalities via Riemann-Liouville fractional integration, Abstract and Applied Analysis, Volume 2012 (2012), Article ID 428983, 10 pages.

[19] M. Z. Sarikaya, E. Set, H. YAldiz AND N. BASAK, Hermite-Hadamard's inequalities for fractional integrals and related fractional inequalities, Mathematical and Computer Modelling, doi:10.1016/j.mcm.2011.12.048, 57 (2013) 2403-2407.

[20] H. YAldiz AND M. Z. SARIKAYA, On the Midpoint type inequalities via generalized fractional integral operators, Xth International Statistics Days Conference, 2016, Giresun, Turkey, pp. 181-189.

[21] M. Z. SARIKAYA AND H. BUdAK, Generalized Hermite-Hadamard type integral inequalities for fractional integrals, Filomat 30:5 (2016), 1315-1326.

[22] J. Wanga, X. Lia And Y. Zhou, Hermite-Hadamard Inequalities Involving Riemann-Liouville Fractional Integrals via s-convex functions and applications to special means, Filomat 30:5 (2016), $1143-1150$.

[23] R. XIANG, Refinements of Hermite-Hadamard type inequalities for convex functions via fractional integrals, J. Appl. Math. \& Informatics Vol. 33(2015), No. 1-2, pp. 119-125.

[24] H. YAldiZ AND M. Z. SARIKAYA, On Hermite-Hadamard type inequalities for fractional integral operators, Research Gate Article, Available online at: https://www.researchgate.net/publication/309824275.

[25] G. S. YAng And K. L. Tseng, On certain integral inequalities related to Hermite-Hadamard inequalities, J. Math. Anal. Appl., 239 (1999), 180-187.

[26] G. S. Yang AND M. C. Hong, A note on Hadamard's inequality, Tamkang J. Math., 28 (1997), 33-37. 